\title{
Changing Trends in Radiotherapy for Glioblastoma Multiforme and Effects on Normal Tissue Doses
}

\author{
Glioblastoma Multiforme Radyoterapisinde Değişen Eğilimler ve Normal Doku \\ Dozlarina Etkileri
}

\author{
(D) Kamuran İbiş1, (1) Canan Köksal2, (1) Uğur Akbaş², (D) Musa Altun¹ \\ 1istanbul University Institute of Oncology, Department of Radiation Oncology, ístanbul, Turkey \\ 2istanbul University Institute of Oncology, Department of Medical Physics, İstanbul, Turkey
}

\begin{abstract}
Introduction: The aim of the study is to reveal the changing trends in radiotherapy (RT) for glioblastoma multiforme (GBM) from past to present and to show the changes in organs at risk (OARs) doses.
\end{abstract}

Methods: We re-planned $10 \mathrm{GBM}$ patients who were previously irradiated. Rigid fusion was performed through pre- and postoperative magnetic resonance imaging (MRI) and simulation computed tomography, and 9 separate volumes were created. While volumes varied from whole brain RT (WBRT) to postoperative two-phase irradiation, RT application ranged from 2-dimensional Co-60 treatment to 3-dimensional volumetric modulated arc therapy (VMAT). OARs were contoured, and doses were noted. A 3 dimensional-conformal RT (3D-CRT) plan of the volume created by preoperative MRI was compared to 3D-CRT and VMAT plans generated by postoperative MRI. Statistical analysis was performed using Paired sample t-test.

Results: During the time of WBRT, normal brain tissue was receiving 45-60 Gy. Through VMAT, the median brain-planning target volume (PTV) D $D_{\text {mean }}$ decreased to 35 Gy. According to both PTV-Radiation Therapy Oncology Group (RTOG) preop and PTVRTOG doses between plans, including brain-PTV initial volume $D_{\text {mean }}$ and brain-PTV boost $\mathrm{D}_{\text {mean }}$ doses. Significantly lower OARs doses were obtained from 3D-CRT plans based on both PTV-RTOG preop and PTV-RTOG postop volumes with the VMAT planning.

Conclusion: With changing trends in RT for GBM, there has been a significant decrease in treatment volumes and normal tissue doses. According to the postoperative volume definition of RTOG, lower normal tissue doses are obtained from VMAT plans, compared to the conformal treatment plans.

Keywords: 3D conformal radiotherapy, intensity modulated radiotherapy, glioblastoma multiforme, volumetric modulated arc therapy

\section{öZ}

Amaç: Çalışmanın amacı glioblastoma multiforme (GBM) radyoterapisindeki (RT) geçmișten günümüze değișen eğilimlerin ortaya konulması ve risk altındaki organ dozlarındaki değișimin gösterilmesidir.

Yöntemler: GBM tanısı ile postopereatif temozolamid ve RT ile tedavi edilen 10 hastanın simülasyon bilgisayarlı tomografi görüntüleri retrospektif olarak incelenerek pre- ve postoperatif manyetik rezonans görüntüleri (MRG) ile rjiid füzyon yapıldı ve 9 ayrı volüm oluşturuldu. Volümler total kranyum ıșınlamadan postoperatif iki fazlı ışınlamaya değişkenlik gösterirken, RT uygulaması 2-boyutlu (2B) Co-60 tedavisinden 3-boyutlu (3B) volumetrik ark tedaviye (VMAT) değișiyordu. Risk altındaki organlar (organs at risk - OAR) konturlandı. Beyin-hedef hacmi planlama (PTV) $D_{\text {mean }}$, beyin sapı $D_{\text {max }}$, göz $D_{\text {max }}$ ipsilateral/ kontralateral, kiazma $\mathrm{D}_{\text {max }}$, koklea $\mathrm{D}_{\text {mean }}$ ipsilateal/kontralateral, lakrimal gland $\mathrm{D}_{\text {max }}$ ipsilateral/konrtalateral, lens $\mathrm{D}_{\max }$ ipsilateral/ kontralateral, pituiter gland $\mathrm{D}_{\max }$ dozları kaydedildi. 7, 8, 9. planlar (preop MRG'den oluşturulan volümün 3B-konformal RT3B-KRT planı ile postop MRG'den oluşturulan 3B-KRT ve VMAT planları) karșılaștırıldı. Paired sample t-testi ile istatistiksel analiz yapıldı.

Bulgular: Total kranyum RT uygulandığı dönemlerde normal beyin dokusunun hepsi 45-60 Gy alırken VMAT ile beyin-PTV $D_{\text {mean }}$ medyan 35 Gy'e düșmüștür. Aynı zamanda göz ve lensler dıșında risk altındaki organlar verilen tüm dozu alarak 60 Gy uygulanan gruplarda doz sınırlamaları așılmıştır. Hem PTV-Radyasyon Terapisi Onkoloji Grubu (RTOG) preop hem de PTV-RTOG postop 3D-CRT planına göre beyin-PTVinitial volüm $D_{\text {mean }}$ ve beyin-PTV $V_{\text {boost }}$ $D_{\text {mean }}$ dozları dahil olmak üzere tüm OAR dozlarında iki plan arasında istatistiksel anlamlı fark yoktu. VMAT planı ile hem PTVRTOG ${ }_{\text {preop }}$ hem de PTV RTOG postop volümlerine göre yapılan 3D-CRT planlarından istatistiksel anlamlı daha düșük OAR dozları elde edildi.

Sonuç: Tarihsel süreçte ışınlanan volüm ve normal doku dozlarında belirgin azalma olmuștur. RTOG'nin postoperatif volüm tanımına göre konformal ve VMAT planları karşılaștırıldığında VMAT planlamada daha düşük normal doku dozları elde edilmektedir.

Anahtar Kelimeler: 3D konformal radyoterapi, yoğunluk ayarlı radyoterapi, glioblastoma multiforme, volümetrik ark tedavisi
Address for Correspondence/Yazıșma Adresi: Kamuran İbiş, İstanbul University Institute of Oncology, Department of Radiation Oncology, İstanbul, Turkey

Phone: +90 5462501973 E-mail: kamuranibis@gmail.com ORCID ID: orcid.org/0000-0001-7928-6264

Cite this article as/Atıf: İbiș K, Köksal C, Akbaș U, Altun M. Changing Trends in Radiotherapy For Glioblastoma Multiforme and Effects on Normal Tissue Doses. İstanbul Med J 2019; 20(1): 49-53.
Received/Geliș Tarihi: 23.07.2018 Accepted/Kabul Tarihi: 23.07.2018

(C) Copyright 2019 by the Istanbul Training and Research Hospital/Istanbul Medical Journal published by Galenos Publishing House.

(C)Telif Hakkı 2019 istanbul Ĕgitim ve Araștırma Hastanesi/Istanbul Tıp Dergisi, Galenos Yayınevi tarafından basılmıștır. 


\section{Introduction}

Glioblastoma multiforme (GBM) is the most deadly and frequent primary brain malignancy in adults (1). Since temozolomide was added to adjuvant radiotherapy (RT), the survival rate has improved (2). Standard treatment of GBM includes surgery, RT, and chemotherapy (3-5). RT has been routinely used in the treatment of brain tumors since the 1940s (6). The use of three-dimensional conformal radiation therapy (3D-CRT) is regarded as the standard treatment $(7,8)$. Intensity-modulated radiation therapy (IMRT) is accepted as an alternative to 3D-CRT and it can minimize treatment-associated side effects (9). The use of proton RT is also increasing (10). Initially, RT for GBM began as whole brain irradiation. The techniques in RT have improved with the development of different doses and applications and with the determination of organs at risk (OARs) and dose limits. The aim of our study was to reveal the changing trends in RT for GBM from past to present and to show the changes in OARs doses.

\section{Methods}

Simulation computerized tomography (simCT) and cranial magnetic resonance imaging (MRI) scans of 10 patients, who were treated with adjuvant temozolomide following concomitant temozolomide and RT after surgical resection, were selected from patient database of istanbul University Institute of Oncology Hospital. After the selection, previous basic scans of the patients were called back to the RT simulation station. No patient actually joined to the simulation process and neither names nor any identifying information related to the study population were used. Due to the retrospective and simulative nature of our study, no informed consent and no ethical approval were obtained. However, the study was performed in compliance with the Declaration of Helsinki. A rigid fusion was performed through MIM software ver. 6.5 (MIM Software Inc., Ohio, USA) using simCT images, pre- and postoperative contrast-enhanced T1 and T2/flair sequences MR images. OARs and dose constraints were determined according to the European Organization for Research and Treatment of Cancer-Advisory Committee on Radiation Oncology Practice guide and the study of Scoccianti et al. (11,12). Optic chiasm, bilateral eyes, bilateral lenses, brainstem, bilateral cochlea, bilateral lacrimal glands, and pituitary gland were determined as the OARs. Brain-planning target volume (PTV) volume was generated through PTV excluded from brain tissue. In two-dimensional planning (2D), fields were manually created using multi-leaf collimators. Twophase target volumes yielded from pre-operative MR images were determined according to the Radiation Therapy Oncology Group (RTOG) 9710 protocol. The RTOG ${ }_{\text {preop }}$ phase 1 volume contained the volume of contrasted tumor with peripheral edema on preoperative MRI scan plus a $2 \mathrm{~cm}$ extra-margin. The RTOG ${ }_{\text {preop }}$ boost volume covered the contrasted lesion (without edema) on the preoperative MRI scan plus

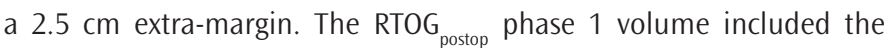
volume of the postoperative cavity and $+/$ - residual tumor in contrast enhanced T1-weighted MRI scans and edema in the postoperative T2weighted MRI scans plus a $2 \mathrm{~cm}$ margin. The RTOG postop $_{\text {boost volume }}$ included the resection cavity $+/$ - residual tumor in contrast enhanced T1-weighted MRI scans plus a $2 \mathrm{~cm}$ margin. 2D treatment planning was used to create plans 1 to $6.3 \mathrm{D}$ planning was made in plans 7 to 9 . Plans
7 and 8 were performed through 3D-CRT, whereas plan-9 was generated through VMAT. The XIO v4.60 treatment planning system was used for all plans except the VMAT plan. The Eclipse V8.9 treatment planning system (Varian Medical Systems, Palo Alto, CA, USA) was used for VMAT. Treatment plans were prepared with 3 full rotation VMAT fields with different collimator angles. VMAT doses were prescribed according to ICRU 83

Co-60 was used for generating plans 1 and 2, and $6 \mathrm{MV}$ was used for the remaining plans. Plan 1: Whole brain RT (WBRT), Co-60 energy, total dose 45 Gy in 25 fractions (fr); Plan 2: WBRT, Co-60 energy, total dose 60 Gy in $30 \mathrm{fr}$; Plan 3: WBRT, 6 MV energy, total dose 45 Gy in 25 fr; Plan 4: WBRT, 6 MV energy, total dose $60 \mathrm{~Gy}$ in $30 \mathrm{fr}$; Plan 5: WBRT in phase 1 followed by tumor bed boost in phase 2, $6 \mathrm{MV}$ energy, phase 1 dose 40 Gy in $20 \mathrm{fr}$ plus boost dose $20 \mathrm{~Gy}$ in $10 \mathrm{fr}$; Plan 6: PTV-RTOG ${ }_{\text {preop }}$ phase 1, 6 MV energy, phase 1 dose 46 Gy in $23 \mathrm{fr}$ plus boost dose $14 \mathrm{~Gy}$ in $7 \mathrm{fr}$; Plan 7: PTV-RTOG ${ }_{\text {preop }}$ phase 1, 6 MV energy, 3D-CRT, phase 1 dose 46 Gy in 23 fr boost dose $14 \mathrm{~Gy}$ in $7 \mathrm{fr}$, Plan 8: PTV-RTOG ${ }_{\text {postop }}$ phase 1, 6 MV energy, 3D-CRT, phase 1 dose 46 Gy in 23 fr plus boost dose $14 \mathrm{~Gy}$ in $7 \mathrm{fr}$; Plan 9: PTV-RTOG ${ }_{\text {postop }}$ phase 1, 6 MV energy, VMAT, 46Gy in 23 fr plus boost 14 Gy in $7 \mathrm{fr}$. Brain-PTV $D_{\text {mean }}$, brainstem $D_{\text {max }}$, bilateral eye $D_{\max }$, optic chiasm $\mathrm{D}_{\max }$, bilateral cochlea $\mathrm{D}_{\text {mean }}$, bilateral lacrimal gland $\mathrm{D}_{\max }$, bilateral lens $\mathrm{D}_{\max }$, and pituitary gland $\mathrm{D}_{\max }$ doses were recorded. The plans 7, 8 and 9 were compared.

\section{Statistical Analysis}

SPSS software version 20 was used for the statistical analysis (IBM Corp., Armonk, NY, USA) using the paired sample t-test. A $p$ value $<0.05$ was considered statistically significant.

\section{Results}

Through VMAT, the median brain-PTV $D_{\text {mean }}$ decreased to 35 Gy while all normal brain tissues received 45-60 Gy. At the same time, the OARs, except for the eye and the lenses, received overdoses in groups given 60 Gy. In Figure 1, the changes in four parameters of 9 plans are presented. Because both PTV-RTOG ${ }_{\text {preop }}$ and PTV-RTOG postop $_{\text {had large treatment }}$ volumes, 3D-CRT planning was possible using two opposing coplanar fields. There was no statistically significant difference between the two plans for all OARs doses, including brain-PTV phase $1 \mathrm{D}_{\text {mean }}$ and brain-PTVboost $\mathrm{D}_{\text {mean }}$ doses. In addition, optic chiasm $\mathrm{D}_{\text {max }}$, bilateral cochlea $\mathrm{D}_{\text {mean }}$, brainstem $\mathrm{D}_{\max }$, pituitary gland $\mathrm{D}_{\max }$, bilateral eye $\mathrm{D}_{\max }$ median dose values were over the dose constraints. The PTV-RTOG 3D-CRT, PTV-RTOG ${ }_{\text {postop }}$ VMAT plans were compared; doses of brain-PTV phase $1 \mathrm{D}_{\text {mean }}$ (median 41.7 Gy vs. $24.1 \mathrm{~Gy}, \mathrm{p}=0.001$ ), brain-PTV boost $\mathrm{D}_{\text {mean }}$ (median $44 \mathrm{~Gy}$ vs $34.4 \mathrm{~Gy}, \mathrm{p}=0.021$ ), chiasm $\mathrm{D}_{\text {max }}$ (62.1 Gy vs. 52.9 $\mathrm{Gy}, \mathrm{p}=0.030$ ), contralateral cochlear $\mathrm{D}_{\text {mean }}$ (median $59 \mathrm{~Gy}$ vs. $13.8 \mathrm{~Gy}$, $\mathrm{p}=0.002$ ), ipsilateral cochlear $\mathrm{D}_{\text {mean }}$ (median $61 \mathrm{~Gy}$ vs. $28.5 \mathrm{~Gy}, \mathrm{p}=0.006$ ) and contralateral eye $\mathrm{D}_{\max }$ (median $36.2 \mathrm{~Gy}$ vs. $23.2 \mathrm{~Gy}, \mathrm{p}=0.022$ ) were

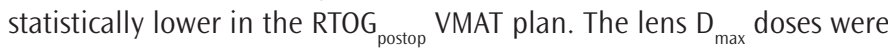
within dose constraints except for one value in both groups, although the RTOG ${ }_{\text {postop }}$ VMAT dose was higher in the lens $D_{\text {max }}$ dose (median 3.9 Gy vs. $7.9 \mathrm{~Gy}, \mathrm{p}=0.005)$. The PTV-RTOG postop 3D-CRT plan was compared to

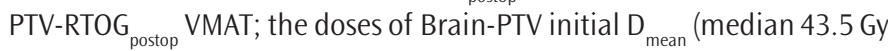
vs. $24.1 \mathrm{~Gy}, \mathrm{p}<0.001$ ), brain-PTV boost $\mathrm{D}_{\text {mean }}$ (median $45.5 \mathrm{~Gy}$ vs. $34.4 \mathrm{~Gy}$, 


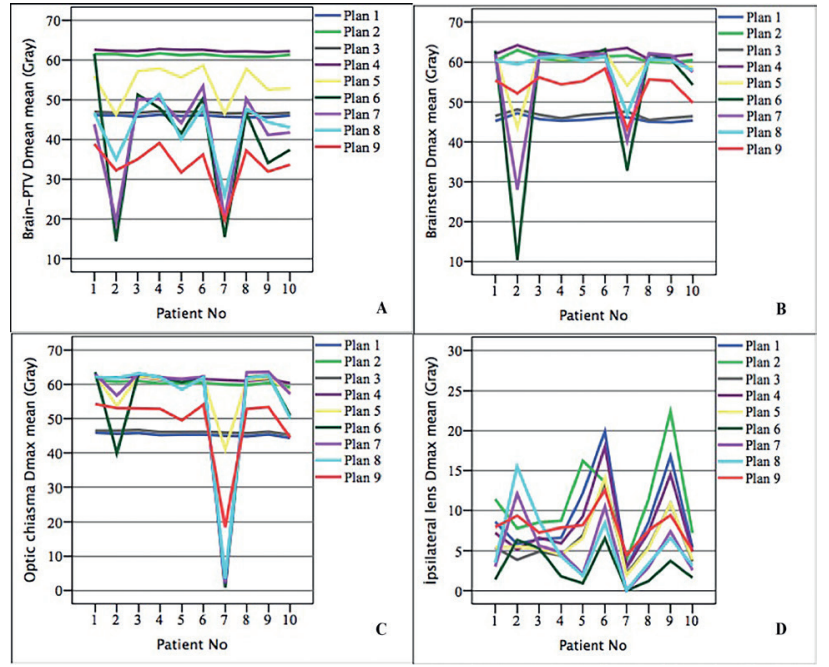

Figure 1. The doses of four organs at risk generated from 9 different plans Plan 1: Whole brain radiotherapy (WBRT), 2D planning, Co-60, total dose 45 Gy in 25 fractions; Plan 2: WBRT, 2D planning, Co-60 energy, total dose 60 Gy in 30 fractions; Plan 3: WBRT, 2D planning, 6 MV energy, total dose 45 Gy in 25 fractions; Plan 4 : WBRT, 2D planning, 6 MV energy, total dose 60 Gy in 30 fractions; Plan 5: WBRT in phase 1 and tumor bed in phase 2, 2D planning, 6 MV energy, phase 1 dose $40 \mathrm{~Gy}$ in 20 fractions plus boost dose 20 Gy in 10 fractions; Plan 6: planning target volume (PTV)-Radiation Therapy Oncology Group (RTOG) preop, 2D planning, 6 MV energy, phase 1 dose 46 Gy in 23 fractions plus boost dose 14 Gy in 7 fractions; Plan 7: PTV-RTOG 3D planning, 6 MV energy, 3D-CRT; phase 1 dose 46 Gy in 23 fractions plus boost dose 14 Gy in 7 fractions; Plan 8: PTV-RTOG dose 46 Gy in 23 fractions plus boost dose 14 Gy in 7 fractions; Plan 9: PTV-RTOG postop 3D planning, 6 MV energy, VMAT, phase 1 dose 46 Gy in 23 fractions plus boost dose 14 Gy in 7 fractions

$p<0.001$ ), optic chiasm $D_{\max }$ (62 Gy vs. $52.9 \mathrm{~Gy}, p=0.029$ ), contralateral cochlea $\mathrm{D}_{\text {mean }}$ (median $48.3 \mathrm{~Gy}$ vs. $13.8 \mathrm{~Gy}, \mathrm{p}=0.029$ ), ipsilateral cochlea $\mathrm{D}_{\text {mean }}$ (median 57.2 Gy vs. $28.5 \mathrm{~Gy}, \mathrm{p}=0.002$ ), brainstem $\mathrm{D}_{\max }$ (median $60.4 \mathrm{~Gy}$ vs. $55.3 \mathrm{~Gy}, \mathrm{p}<0.001$ ), pituitary gland $\mathrm{D}_{\max }$ (median $61.4 \mathrm{~Gy}$ vs. $46.7 \mathrm{~Gy}, \mathrm{p}=0.005$ ), contralateral eye $\mathrm{D}_{\max }$ (median $40.1 \mathrm{~Gy}$ vs. $23.2 \mathrm{~Gy}$, $\mathrm{p}=0.007$ ), and contralateral lacrimal gland $\mathrm{D}_{\max }$ (median 36.4 Gy vs.

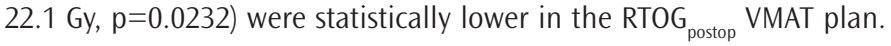
3D-CRT, made in two phases according to PTV RTOG ${ }_{\text {preop }}$ and RTOG volumes, and the OARs doses, made in two phase VMAT plan according to the RTOG ${ }_{\text {postop }}$ volume, are given in Table 1.

\section{Discussion}

The routine use of RT in brain tumors began in the 1940s with kilovoltage X-rays $(13,14)$. In the 1960s, 45-60 Gy RT was applied to the entire brain with megavoltage X-rays or Co-60 teletherapy devices $(15,16)$. We found that all the OARs and whole brain tissue received a median [standard deviation (SD)] dose of 45 (3) Gy, except for lenses, when 45 Gy WBRT was delivered after 2D planning through Co-60 or linear accelerators. The lenses were the only normal tissue that could be protected with protection blocks anatomically because of being away from the brain tissue. In 1979, Walker et al. (13) found that 50-60 Gy doses were associated with increased survival when compared with doses $\leq 45 \mathrm{~Gy}$. In those days, 50 - 60 Gy was applied to the whole brain. When we performed 60 Gy 2D WBRT with Co-60 and linear accelerators, we found that all the OARs and the whole brain were receiving a median (SD) dose of 60 (3) Gy, except for the lenses. All of the OARs exceeded the dose constraints that need to be considered today. In the 1970s, some centers were delivering an initial dose of 30-46 Gy as WBRT, followed by 20-30 Gy irradiation to the tumor bed, so two-phase treatment was used (17-21). Initially, CT (in the 1970s and 1980s) and then MRI (in the late 1980s) was used for delineating RT target volumes (22). Afterwards, two-phase treatment plans including phase 1 and boost volumes were used by abandoning WBRT. Previously, two-phase target volumes were created with the aid of preoperative imaging, predominantly considering preoperative tumor and edema volumes. In this study, we compared two different two-phase plans using 6 MV energy through WBRT (40 Gy/20 fr) + boost (20 Gy/10 fr), PTV-RTOG ${ }_{\text {preop }}$ phase 1 (46 Gy /23 fr) + PTV-RTOGboost (14 Gy/7 fr) volumes generated according to RTOG 9710. Between these two plans, there were no significant differences in terms of Brain-PTVinitial $D_{\text {mean }}$, chiasm $\mathrm{D}_{\max }$, and brainstem $\mathrm{D}_{\max }$ doses. However, in the plans generated according to RTOG 9710, the brain-PTV boost $\mathrm{D}_{\text {mean }}$, contralateral cochlear $\mathrm{D}_{\text {mean }}$, contralateral eye $\mathrm{D}_{\max }$, contralateral lacrimal gland $\mathrm{D}_{\max }$, ipsilateral lacrimal gland $\mathrm{D}_{\max }$, contralateral lens $\mathrm{D}_{\max }$, and ipsilateral lens $D_{\max }$ doses were significantly lower, so normal OARs were better spared. In addition to technological advances, approaches in generating irradiation volumes for GBM were changing in accordance with clinical evaluations. The side effects of RT in neurological tissues have led to this change. Brain irradiation is associated with neurotoxic side effects including radionecrosis and cognitive impairment $(23,24)$. For the first time, Chang et al. (25) compared the RTOG volume, including peritumoral edema in preoperative MRI and target volumes in which peritumoral edema is not taken into consideration, but in which the residual tumor in the postoperative MRI +/- is targeted. According to both RTOG and MD Anderson Cancer Center plans, they revealed that $90 \%$ of the recurrences were central and within the area. Today, guidelines recommend using a postoperative MRI while defining/ delineation target volume for RT in GBM. Different cooperative groups have target volume delineation that includes or excludes peritumoral edema (26). In this study, we compared the 3D-CRT plan of preoperative volume based on RTOG, the 3D-CRT plan of postoperative volume based on RTOG, and the VMAT plan of postoperative volume based on RTOG. The doses of OARs obtained in the VMAT plan, made in two phases according to PTV-RTOG preop $_{\text {and PTV-RTOG }}$ postop volumes, and made in two

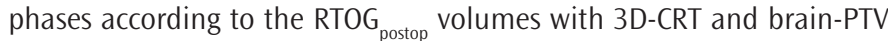
initial / boost $\mathrm{D}_{\text {mean }}$ were significantly lower. Although 3D-CRT is accepted as the standard in general use, IMRT and VMAT use are increasingly used in tumors with large volume and near OARs (9-11). 3D-CRT is often sufficient in cases of spherical frontal or parietal tumors, whereas more successful plans can be made with IMRT or VMAT in irregularly shaped brainstem or near-orbit-like tumors $(27,28)$. VMAT is usually preferred, because it provides a faster treatment plan and treatment application with conformality similar to IMRT. Today, the dose to be preferred in a young patient, who is fit and whose performance score is good, is $60 \mathrm{~Gy}$ in 30 fractions with concomitant temozolomide (11). Hypofractionated schedules are suitable for elderly or patients with a poor performance status (such as 40 Gy in 15 fractions or 34 Gy in 10 fractions) $(29,30)$.

\section{Conclusion}

RT for disease control of GBM is important. With changing trends in RT for GBM, there has been a significant decrease in the treatment volumes and normal tissue doses. Today, the volume is generated according 
Table 1. Comparison of normal tissue doses generated from 3 different radiotherapy plans according to Radiation Therapy Oncology Group volumes

\begin{tabular}{|c|c|c|c|c|c|c|}
\hline & $\begin{array}{l}\text { A } \\
\text { Mean (SD) } \\
\text { median (min-max) }\end{array}$ & $\begin{array}{l}\text { B } \\
\text { Mean (SD) } \\
\text { median (min-max) }\end{array}$ & $\begin{array}{l}\text { C } \\
\text { Mean (SD) } \\
\text { median (min-max) }\end{array}$ & $\begin{array}{l}\text { A-B } \\
\text { p value }\end{array}$ & $\begin{array}{l}\mathrm{A}-\mathrm{C} \\
\mathrm{p} \text { value }\end{array}$ & $\begin{array}{l}B-C \\
\text { p value }\end{array}$ \\
\hline Brain-PTV phase I $D_{\text {mean }}$ & $\begin{array}{l}39.6(12) \\
41.7(18.1-52.4)\end{array}$ & $\begin{array}{l}40.2(8.4) \\
43.5(22.6-48.7)\end{array}$ & $\begin{array}{l}24.3(3.3) \\
24.1(16.9-28.5)\end{array}$ & 0.693 & 0.001 & $<0.001$ \\
\hline Brain-PTV boost $\mathrm{D}_{\text {mean }}$ & $\begin{array}{l}41.4(12.2) \\
44(19.3-53.4)\end{array}$ & $\begin{array}{l}42.9(7.6) \\
45.5(25.8-51.4)\end{array}$ & $\begin{array}{l}33.6(5.6) \\
34.4(19.8-39.1)\end{array}$ & 0.458 & 0.021 & $<0.001$ \\
\hline Optic chiasma $\mathrm{D}_{\max }$ & $\begin{array}{l}55.5(18.9) \\
62.1(2.2-63.6)\end{array}$ & $\begin{array}{l}54.8(18.5) \\
62(3.4-63.2)\end{array}$ & $\begin{array}{l}48.6(11) \\
52.9(18.5-54.3)\end{array}$ & 0.463 & 0.030 & 0.029 \\
\hline Contralateral cochlea $\mathrm{D}_{\text {mean }}$ & $\begin{array}{l}42.2(28.1) \\
59(0.7-60.9)\end{array}$ & $\begin{array}{l}38.4(22.2) \\
48.3(1.7-56.8)\end{array}$ & $\begin{array}{l}12(6.9) \\
13.8(2.3-20.2)\end{array}$ & 0.183 & 0.002 & 0.001 \\
\hline Ipsilateral cochlea $D_{\text {mean }}$ & $\begin{array}{l}43.6(29.3) \\
61(0.6-63)\end{array}$ & $\begin{array}{l}42.7(25.3) \\
57.2(1.5-60.8)\end{array}$ & $\begin{array}{l}22.9(11.5) \\
28.5(2.8-33.5)\end{array}$ & 0.624 & 0.006 & 0.002 \\
\hline Brainstem $\mathrm{D}_{\max }$ & $\begin{array}{l}55.8(11.9) \\
61.6(28-62.1)\end{array}$ & $\begin{array}{l}59(4.4) \\
60.4(47-61.4)\end{array}$ & $\begin{array}{l}53.6(4.3) \\
55.3(43.2-58.4)\end{array}$ & 0.349 & 0.484 & $<0.001$ \\
\hline $\begin{array}{l}\text { Pituitary gland } \\
D_{\max }\end{array}$ & $\begin{array}{l}48.1(24.4) \\
62.1(1.8-63.1)\end{array}$ & $\begin{array}{l}53.5(18.6) \\
61.4(2.4-62.6)\end{array}$ & $\begin{array}{l}41.9(12.6) \\
46.7(15.1-51.8)\end{array}$ & 0.289 & 0.151 & 0.005 \\
\hline Contralateral eye $D_{\max }$ & $\begin{array}{l}35(21.3) \\
36.2(0.1-58.4)\end{array}$ & $\begin{array}{l}37.9(21) \\
40.1(0.2-60)\end{array}$ & $\begin{array}{l}23.4(9) \\
23.2(7.9-38.2)\end{array}$ & 0.097 & 0.022 & 0.007 \\
\hline Ipsilateral eye $D_{\max }$ & $\begin{array}{l}38.3(23.5) \\
41.3(0.1-62.6)\end{array}$ & $\begin{array}{l}42(22.8) \\
46.5(0.2-62.3)\end{array}$ & $\begin{array}{l}34.5(13.2) \\
35.7(8.5-49.4)\end{array}$ & 0.100 & 0.333 & 0.053 \\
\hline Contralateral lacrimal gland $\mathrm{D}_{\max }$ & $\begin{array}{l}30.3(21) \\
34.3(0.2-58.2)\end{array}$ & $\begin{array}{l}32.4(20.5) \\
36.4(0.2-60)\end{array}$ & $\begin{array}{l}21.9(8) \\
22.1(10.1-35.5)\end{array}$ & 0.166 & 0.079 & 0.032 \\
\hline Ipsilateral lacrimal gland $\mathrm{D}_{\max }$ & $\begin{array}{l}35.7(23.6) \\
40.6(0.1-61.4)\end{array}$ & $\begin{array}{l}39.9(22.9) \\
47.6(0.2-62.2)\end{array}$ & $\begin{array}{l}32.3(10.6) \\
36.5(9.8-44)\end{array}$ & 0.063 & 0.475 & 0.095 \\
\hline Contralateral lens $\mathrm{D}_{\max }$ & $\begin{array}{l}5.9(4.2) \\
5.4(0.06-12.7)\end{array}$ & $\begin{array}{l}6.2(4.2) \\
6(0.1-15.3)\end{array}$ & $\begin{array}{l}7.7(2) \\
7.7(4.2-11.9)\end{array}$ & 0.619 & 0.084 & 0.183 \\
\hline Ipsilateral lens $\mathrm{D}_{\max }$ & $\begin{array}{l}5.1(3.8) \\
3.9(0.05-12)\end{array}$ & $\begin{array}{l}5.5(4.4) \\
3.9(0.1-15.5)\end{array}$ & $\begin{array}{l}7.9(2.3) \\
7.9(4.4-12.5)\end{array}$ & 0.415 & 0.005 & 0.066 \\
\hline
\end{tabular}

to the post-operative cranial MRI in the target volume delineation. When conformal and VMAT plans are compared according to the postoperative definition of RTOG, lower normal tissue doses are obtained in VMAT plans. 3D-CRT can be used depending on tumor location, while VMAT is advantageous when the treatment volume is close to OARs.

Ethics Committee Approval: Retrospective study.

Informed Consent: Retrospective study.

Peer-review: Externally and internally peer-reviewed.

Author Contributions: Concept - K.I.; Design - K.I., M.A.; Supervision - K.I.; Resources - K.I. ; Materials - K.I.., M.A.; Data Collection and/or
Processing - C.K., U.A.; Analysis and/or Interpretation - K.I.; Literature Search - K.I.; Writing Manuscript - K.I.; Critical Review - K.I., M.A.

Conflict of interest: The authors declare no conflict of interest.

Financial disclosure: No financial support was used for the study.

\section{References}

1. Fisher JL, Schwartzbaum JA, Wrench M, Wiemels JL. Epidemiology of brain tumors. Neurol Clin 2007; 25: 867-90.

2. Stupp R, Hegi ME, Mason WP, van den Bent MJ, Taphoorn MJ, Janzer RC, et al. Effects of radiotherapy with concomitant and adjuvant temozolomide versus radiotherapy alone on survival in glioblastoma in a randomised phase III study: 5-year analysis of the EORTC-NCIC trial. Lancet Oncol 2009; 10: 459-66. 
3. Laperriere N, Zuraw L, Cairncross G. Radiotherapy for newly diagnosed malignant glioma in adults: a systematic review. Radiother Oncol 2002; 64: 259-73.

4. Simpson JR, Horton J, Scott C, Curran WJ, Rubin P, Fischbach J, et al. Influence of location and extent of surgical resection on survival of patients with glioblastoma multiforme: results of three consecutive Radiation Therapy Oncology Group (RTOG) clinical trials. Int J Radiation Oncol Biol Phys 1993; 26: 239-44.

5. Nitta T, Sato K. Prognostic implications of extent of surgical resection in patients with intracranial malignant glioma. Cancer 1995; 75: 2727-31.

6. Gzell C, Back M, Wheeler H, Bailey D, Foote M. Radiotherapy in Glioblastoma: the past, the present and the future. Clin Oncol (R Coll Radiol) 2017; 29: 15-25.

7. Kortmann RD, Timmermann B, Taylor RE, Scarzello G, Plasswilm L, Paulsen $\mathrm{F}$, et al. Current and future strategies in radiotherapy of childhood lowgrade glioma of the brain. Part I: Treatment modalities of radiation therapy. Strahlenter Oncol 2003; 179: 509-20.

8. Chan MD. Recent technical advances and indications for radiation therapy in low-grade glioma. Semin Radiat Oncol 2015; 25: 189-96.

9. Aherne NJ, Benjamin LC, Horsley PJ, Silva T, Wilcox S, Amalaseelan J, et al. Improved outcomes with intensity modulated radiation therapy combined with temozolomide for newly diagnosed glioblastoma multiforme. Neurol Res Int 2014; 2014: 945620.

10. Shaffer R, Nichol AM, Vollans E, Fong M, Nakano S, Moiseenko V, et al. A comparison of volumetric modulated arc therapy and conventional intensitymodulated radiotherapy for frontal and temporal high-grade gliomas. Int J Radiat Oncol Biol Phys 2010; 76: 1177-84.

11. Niyazi M, Brada M, Chalmers AJ, Combs SE, Erridge SC, Fiorentino A, et al. ESTRO-ACROP guideline "target delineation of glioblastomas". Radiother Oncol 2016; 118: 35-42.

12. Scoccianti S, Detti B, Gadda D, Greto D, Furfaro I, Meacci F, et al. Organs at risk in the brain and their dose-constraints in adults and in children: A radiation oncologist's guide for delineation in everyday practice. Radiother Oncol 2015; 114: 230-8.

13. Walker MD, Strike TA, Sheline GE. An analysis of dose-effect relationship in the radiotherapy in the radiotherapy of malignant gliomas. Int J Radiat Oncol Biol Phys 1979; 5: 1725-31.

14. Onoyama Y, Abe M, Yabumoto E, Sakamoto T, Nishidai T. Radiation therapy in the treatment of glioblastoma. Am J Roentgenol 1976; 126: 481-92.

15. Wilson CB. Glioblastoma Multiforme: present status. Arch Neurol 1964; 11: 562-8.

16. Edland RW, Javid M, Ansfield FJ. Glioblastoma multiforme. Am J Roentgenol 1971; 111: 337-42.
17. Brisman R, Housepian EM, Chang C, Duffy P, Balis E. Adjuvant nitrosourea therapy for glioblastoma. Arch Neurol 1976; 33: 745-50.

18. Hochberg FH, Linggood R, Wolfson L, Baker WH, Kornblith P. Quality and duration of survival in glioblastoma multiforme: combined surgical, radiation, and lomustine therapy. JAMA 1979; 241: 1016-8.

19. McCullough DC, Huang HK, DeMichelle D, Manz HJ, Sinks LF. Correlation between volumetric CT imaging and autopsy measurements of glioblastoma size. Comput Tomogr 1973; 3: 133-41.

20. Comella G, Scoppa G, Marco MD, Ianniello GP, Melillo G, Coucourde F, et al. Radiotherapy and combination chemotherapy with carmustine, vincristine, and procarbazine (BVP) in primary brain tumors. J Neurooncol 1985; 3: 13-7.

21. Marsa GW, Goffinet DR, Rubinstein LJ, Bagshaw MA. Megavoltage irradiation in the treatment of gliomas of the brain and spinal cord. Cancer 1975; 36: 1681-9.

22. Ten Haken RK, Thornton Jr AF, Sandler HM, LaVigne ML, Quint DJ, Fraass $\mathrm{BA}$, et al. A quantitative assessment of the addition of MRI to CT-based, 3D treatment planning of brain tumors. Radiother Oncol 1992; 25: 121-33.

23. Emami B, Lyman J, Brown A, Coia L, Goitein M, Munzenrider JE, et al. Tolerance of normal tissue to therapeutic irradiation. Int J Radiat Oncol Biol Phys 1991; 21: $109-22$

24. Torres IJ, Mundt AJ, Sweeney PJ, Llanes-Macy S, Dunaway L, Castillo M, et al. A longitudinal neuropsychological study of partial brain radiation in adults with brain tumors. Neurology 2003; 60: 1113-8.

25. Chang EL, Akyurek S, Avalos T, Rebueno N, Spicer C, Garcia J, et al. Evaluation pf peritumoral edema in the delineation of radiotherapy clinical target volumes for glioblastoma. Int J Radiat Oncol Biol Phys 2007; 66: 144-50.

26. Cabrera AR, Kirkpatrick JP, Fiveash JB, Shih HA, Koay EJ, Lutz S, et al. Radiation therapy for glioblastoma: Executive summary of an American Society for Radiation Oncology evidence-based clinical practice guideline. Pract. Radiat Oncol 2016; 6: 217-25.

27. Amelio D, Lorentini S, Schwarz M, Amichetti M. Intensity-modulated radiation therapy in newly diagnosed glioblastoma: a systematic review on clinical and technical issues. Radiother Oncol 2010; 97: 361-9.

28. Lorentini S, Amelio D, Giri MG, Fellin F, Meliado G, Rizzotti A, et al. IMRT or 3D-CRT in glioblastoma? A dosimetric criterion for patient selection. Technol Cancer Res Treat 2013; 12: 411-20.

29. Roa W, Brasher PM, Bauman G, Anthes M, Bruera E, Chan A, et al. Abbreviated course of radiation therapy in older patients with glioblastoma multiforme. A prospective randomized clinical trial. J Clin Oncol 2004; 22: 1583-8.

30. Malmstrom A, Gronberg BH, Marosi C, Stupp R, Frappaz D, Schultz H, et al. Temozolomide versus standard 6-week radiotherapy versus hypofractionated radiotherapy in patients older than 60 years with glioblastoma: the Nordic randomised, phase 3 trial. Lancet Oncol 2012; 13: 916-26. 